\title{
Alpha-1-Antichymotrypsin Gene Polymorphism and Risk for Sporadic Alzheimer's Disease in a German Population
}

\author{
Sibylle G. Schwab Metin Bagli Andreas Papassotiropoulos Frank Jessen \\ Wolfgang Maier Marie Luise Rao Reinhard Heun
}

Department of Psychiatry, University of Bonn, Germany

\section{Key Words}

$\alpha_{1}$-Antichymotrypsin · Apolipoprotein E · Alzheimer's disease $\cdot$ Association

\begin{abstract}
The A allele of a common A-T polymorphism in the signal peptide of $\alpha_{1}$-antichymotrypsin gene (ACT) has been reported to contribute a two- to threefold increased risk to Alzheimer's disease (AD) patients who carry the apolipoprotein E \&4 (APOE \&4) genotype. Since the ACT expression in $A D$ brains is enhanced in particular in areas that develop amyloid plaques, the ACT polymorphism is considered to be a good candidate gene. We have analyzed this polymorphism in $102 \mathrm{AD}$ patients and 191 matched controls, all originating from Western Germany. No statistically significant differences in allele frequencies and in genotype distribution of ACT could be shown between $A D$ patients and controls. When we analyzed the polymorphism in APOE 84 carriers, no overrepresentation in our $A D$ group could be shown for the $A C T^{*} A A$ genotype carriers.
\end{abstract}

\footnotetext{
Copyright $\odot 1999$ S. Karger AG, Basel
}

\section{Introduction}

Alzheimer's disease (AD) is a genetically heterogeneous neurodegenerative disorder that is the most frequent cause of dementia in the elderly. It is well established that early-onset forms of AD often show an autosomal dominant pattern of inheritance which is mainly due to mutations in the amyloid precursor protein (APP), presenilin 1 (PS1) or presenilin 2 gene (PS2) [1]. In contrast, the more common late-onset and sporadic forms of $\mathrm{AD}$ exhibit a more complex pattern of inheritance. In the last 5 years apolipoprotein E $\varepsilon 4$ (APOE $\varepsilon 4$ ) has been well established as a major risk factor [1]. Most recently it has been suggested that $\alpha_{2}$-macroglobulin is associated with late-onset $\mathrm{AD}$ [2]. In addition, there may be other genes acting independently or interactively in the pathogenesis of the disease. One candidate gene that might play a role in the development of the disease is $\alpha_{1}$-antichymotrypsin (ACT). In the filamentous deposits found in brains of AD patients ACT binds to $\beta$-amyloid peptide with high affinity. Thus it is thought that ACT serves as a strong activating factor in the polymerization of $\beta$-amyloid peptide into amyloid filaments [3, 4].

\footnotetext{
Sibylle G. Schwab

University of Bonn, Department of Psychiatry, Molecular Genetics Laboratory Wilhelmstrasse 31

D-53111 Bonn (Germany)

Tel. +49 228287 2352, Fax +49 228287 2617, E-Mail schwab@uni-bonn.de

\begin{tabular}{ll}
\hline KARGER & (1 1999 S. Karger AG, Basel \\
Fax +4161306 1234 $34-8008 / 99 / 0106-0469 \$ 17.50 / 0$ \\
$\begin{array}{l}\text { E-Mail karger@karger.ch } \\
\text { www.karger.com }\end{array}$ & $\begin{array}{l}\text { Accessible online at: } \\
\text { www.karger.com/journals/dem }\end{array}$
\end{tabular}


Table 1. Comparison of ACT genotype and allele frequency in AD patients and controls

\begin{tabular}{llc}
\hline Genotype $^{1}$ & AD patients $(\mathrm{n}=102)$ & Controls $(\mathrm{n}=191)$ \\
\hline ACT*AT & $52(51 \%)$ & $115(60.2 \%)$ \\
ACT*AA & $30(29.4 \%)$ & $46(24.1 \%)$ \\
ACT*TT & $20(19.6 \%)$ & $30(15.7 \%)$ \\
Allele frequency & & \\
\hline ACT*A $^{*}$ ACT & 0.549 & 0.542 \\
ACT & 0.451 & 0.458 \\
\hline
\end{tabular}

$1 \quad \chi^{2}=2.3 ;$ d.f. $=2 ; p=0.32$.

Table 2. ACT genotypes dependent on $\mathrm{APOE} \& 4$ genotypes in $\mathrm{AD}$ patients and controls

\begin{tabular}{|c|c|c|c|c|}
\hline \multirow[t]{2}{*}{ Genotype } & \multicolumn{2}{|c|}{ AD patients } & \multicolumn{2}{|c|}{ Controls } \\
\hline & $\mathrm{n}$ & $\%$ & $\mathrm{n}$ & $\%$ \\
\hline \multicolumn{5}{|c|}{ APO $\varepsilon 4$ noncarrier ${ }^{1}$} \\
\hline ACT*AT & 24 & 60.0 & 84 & 59.2 \\
\hline $\mathrm{ACT}^{*} \mathrm{AA}$ & 13 & 32.5 & 36 & 25.4 \\
\hline ACT*TT & 3 & 7.5 & 22 & 15.4 \\
\hline \multicolumn{5}{|c|}{ APOE $\varepsilon 4$ carrier $^{2}$} \\
\hline $\mathrm{ACT}^{*} \mathrm{AT}$ & 28 & 45.2 & 31 & 63.3 \\
\hline $\mathrm{ACT}^{*} \mathrm{AA}$ & 17 & 27.4 & 10 & 20.4 \\
\hline $\mathrm{ACT}^{*} \mathrm{TT}$ & 17 & 27.4 & 8 & 16.3 \\
\hline
\end{tabular}

APOE $\varepsilon 4$ noncarriers: 40 AD patients, 142 controls. APOE $\varepsilon 4$ carriers: $62 \mathrm{AD}$ patients, 49 controls.

$1 \quad \chi^{2}=2.1 ;$ d.f. $=2 ; \mathrm{p}=0.36$

$2 \chi^{2}=3.7 ;$ d.f. $=2 ; \mathrm{p}=0.16$.

Kamboh et al. [5] were the first to report an association between a common polymorphism in the signal peptide of $\mathrm{ACT}$ and APOE $\varepsilon 4$ carriers with AD. On the background of controversial results on association of ACT concerning the German population, it was our intention to analyze this polymorphism together with the APOE polymorphism in a German sample of 102 sporadic, late-onset AD patients and 191 controls. Patients and controls were recruited from the general population. No association between $\mathrm{ACT}^{*} \mathrm{~A}$ allele neither in APOE $\varepsilon 4$ carriers nor in our total AD group was detected.

\section{Material and Methods}

\section{Patients}

AD patients were recruited from the outpatient memory disorder clinic of the Psychiatric Department of the University of Bonn. Diagnosis of probable $\mathrm{AD}$ was performed by standard clinical evaluation according to NINCDS-ADRDA criteria. Medical and family history, general medical and neurological examination, psychiatric interview, neurological testing, blood and cerebrospinal fluid studies as well as CT scans were carried out to exclude other forms of dementia. Altogether $102 \mathrm{AD}$ patients were included in this study. The mean age was 74.4 years (range 51-101 years), 68 of them were female and 34 male patients. Patients with familial (autosomal-dominant) AD were not included.

\section{Controls}

Supported by the local Census Bureau and the regional Board of Data Protection (Nordrhein-Westfalen, Germany) a random sample of subjects over 50 years was selected from the general population. The control group comprised 191 nondemented subjects. They were evaluated based upon a psychiatric interview and neurological testing. Mean age was 70.6 years (range 50-100 years), 99 were female and 92 male subjects. Informed consent was obtained for all patients and controls.

\section{Genotyping}

DNA was extracted from whole blood using Quiagen Blood DNA Kit (Quiagen, Hilden, Germany). The APOE polymorphism was analyzed by a PCR-based method as described by Hixon and Vernier [6]. The ACT polymorphism also was analyzed by a PCR-based method as described by Kamboh et al. [5].

\section{Statistical Analysis}

$\chi^{2}$ distribution and Fisher's exact test were used for analysis of the data. Power calculations were carried out using arcsine transformations of percentages as proposed by Lipsey [7]

\section{Results}

Altogether 102 AD patients and 191 matched controls were genotyped for the ACT polymorphism and the APOE polymorphism. Hardy-Weinberg equilibrium could be demonstrated for both polymorphisms in patients and controls. ACT was first analyzed neglecting the APOE genotype. Kamboh et al. [5] reported an increased risk for carriers of the ACT*AA genotype. In our analysis the ACT*AA genotype was detected in 30 patients (29.4\%) and in 46 controls $(24.1 \%) ; 20 \mathrm{AD}$ patients $(19.6 \%)$ and 30 controls (15.7\%) carried the ACT*TT genotype. This difference was statistically not significant $\left(\chi^{2}=2.3\right.$; d.f. $=2, p=0.32$, table 1). Breakdown of the samples according to age and sex had no influence on this distribution (data not shown).

Since an increased risk was reported for ACT*AA carriers that in addition carry the APOE $\varepsilon 4$ genotype we 
grouped the $\mathrm{AD}$ patients and controls in individuals carrying the APOE $\varepsilon 4$ genotype or not. Thirteen patients $(32.5 \%)$ and 36 controls $(25.4 \%)$ without APOE $\varepsilon 4$ allele were homozygous for ACT*A, 3 patients $(7.5 \%)$ and 22 controls (15.4\%) were homozygous for ACT*T. Seventeen patients $(27.4 \%)$ and 10 controls (20.4\%) among the carriers of the APOE $\varepsilon 4$ allele had an ACT*AA genotype while $17 \mathrm{AD}$ patients (27.4\%) and 8 controls (16.3\%) showed an ACT*TT genotype. These data did not reach any statistical significance when Fisher's exact test was applied. For the APOE $\varepsilon 4$ noncarriers a $p$ value of 0.36 and for the APOE $\varepsilon 4$ carriers, a $p$ value of 0.16 was obtained (table 2).

Power calculations revealed a statistical power of $72 \%$ to detect an effect of the size originally reported by Kamboh et al. [5].

\section{Discussion}

In the present study we could not observe a significant influence of the ACT genotype on the risk of AD. After the first report on a modification of an APOE $\varepsilon 4$-associated risk for AD by ACT [5] a number of contradictory results have been published. Yoshiiwa et al. [8] replicated the original finding in a Japanese population, Thome et al. [9] in a German population, Ezquerra et al. [10], working with a Spanish population, could only replicate the finding in non-APOE $\varepsilon 4$ carriers. Nacmias et al. [11] obtained some hint that ACT may interact with APOE in their late-onset familial AD cases. In 1997, Kamboh et al. [12] also reported a gender-specific effect. However, most groups could not replicate the finding even if they break down their samples according to sex and age [13-23].

Power calculations showed that the statistical power of our sample to detect the originally reported differences in the distribution of the ACT polymorphism between AD patients and healthy subjects stratified by the presence or absence of the APOE $\varepsilon 4$ allele was $72 \%$. In context with the other negative results reported in the literature [1323] we conclude that the ACT genotype might have no or only a minor effect on AD risk in our population.

Moreover, results of association studies using a casecontrol design are explicitly sensitive to stratification. In $\mathrm{AD}$ it is almost impossible to perform family-based association studies. In order to circumvent stratification problems, we used a sample that was carefully matched for age, gender and ethnicity.

When we assume genetic heterogeneity between different populations, we cannot exclude that ACT may have an effect on $\mathrm{AD}$ risk in some populations. However, regarding all the contradictory results, this effect, if present, might be a very minor one.

\section{Acknowledgment}

We want to thank Godwing Insiun for language editing of the manuscript. This work was supported by grants of the Deutsche Forschungsgemeinschaft to R.H. (He 2318/1-2).

\section{References}

1 Sandbrink R, Hartmann T, Masters CL, Beyreuther K: Genes contributing to Alzheimer's disease. Mol Psychiatry 1996;1:27-40.

2 Blacker D, Wilcox MA, Laird NM, Rodes L, Horvath SM, Go RCP, Perry R, Watson B, Bassett S, McInnis MG, Albert MS, Hyman BT, Tanzi RE: Alpha-2 macroglobulin is genetically associated with Alzheimer disease. Nat Genet 1998;19:357-360.

3 Ma J, Yee A, Brewer HB Jr, Das S, Potter H: Amyloid associated proteins $\alpha_{1}$-antichymotrypsin and apolipoprotein E promote assembly of Alzheimer $\beta$-protein into filaments. Nature 1994;372:92-94

4 Fraser PE, Nguyen JT, McLachlan DR, Abraham CR, Kirschner DA: $\alpha_{1}$-Antichymotrypsin binding to Alzheimer $A \beta$ peptides is sequence specific and induces fibril disaggregation in vitro. J Neurochem 1993;61:298-305.
5 Kamboh MI, Sanghera DK, Ferrell RE, DeKosky ST: APOE*4-associated Alzheimer's disease risk is modified by $\alpha_{1}$-antichymotrypsin polymorphism. Nat Genet 1995;10:486488.

6 Hixson JE, Vernier DT: Restriction isotyping of human apolipoprotein E by gene amplification and cleavage with Hhal. J Lipid Res 1990; 31:545-548.

7 Lipsey MW: Design Sensitivity: Statistical Power for Experimental Research. Newbury Park, Sage, 1990, pp 76-98.

8 Yoshiiwa A, Kamino K, Yamamoto H, Kobayashi T, Imagawa M, Nonomura Y, Yoneda H, Sakai T, Nishiwaki Y, Sato N, Rakugi H, Miki T, Ogihara T: Alpha-1-antichymotrypsin as a risk modifier for late-onset Alzheimer's disease in Japanese apolipoprotein E epsilon 4 allele carriers. Ann Neurol 1997;42:115-117.
9 Thome J, Baumer A, Kornhuber J, Rosler M, Riederer P: Alpha-1-antichymotrypsin bi-allele polymorphism, apolipoprotein-E tri-allele polymorphism and genetic risk of Alzheimer's syndrome. J Neural Transm Park Dis Dement Sect 1995;10:207-212.

10 Ezquerra M, Blesa R, Tolosa E, Ballesta F, Oliva $\mathrm{R}$ : Alpha-antichymotrypsin gene polymorphism and risk for Alzheimer's disease in the Spanish population. Neurosci Lett 1998;240: 107-109.

11 Nacmias B, Marcon G, Tedde A, Forleo P, Latorraca S, Piacentini S, Amaducci L, Sorbi S: Implication of alpha-1-antichymotrypsin polymorphism in familial Alzheimer's disease. Neurosci Lett 1998;244:85-88. 
12 Kamboh MI, Sanghera DK, Aston CE, Bunker $\mathrm{CH}$, Hamman RF, Ferrell RE, DeKosky ST: Gender-specific nonrandom association between the alpha-1-antichymotrypsin and apolipoprotein E polymorphisms in the general population and its implication for the risk of Alzheimer's disease. Genet Epidemiol 1997;14: 169-180.

13 Haines JL, Pritchard ML, Saunders AM, Schildkraut JM, Growdon JH, Gaskell PC, Farrer LA, Auerbach SA, Gusella JF, Locke PA, Rosi BL, Yamaoka L, Small GW, Conneally PM, Roses AD, Pericak-Vance MA: No genetic effect of alpha-1-antichymotrypsin in Alzheimer disease. Genomics 1996;33:53-56.

14 Müller U, Bödeker R-H, Gerundt I, Kurz A: Lack of association between $\alpha_{1}$-antichymotrypsin polymorphism, Alzheimer's disease, and allele $\varepsilon 4$ of apolipoprotein E. Neurology 1996;47: 1575-1577.

15 Nacmias B, Tedde A, Latorraca S, Piacentini S, Bracco L, Amaducci L, Guarnieri BM, Petruzzi C, Ortenzi L, Sorbi S: Apolipoprotein E and alpha-1-antichymotrypsin polymorphism in Alzheimer's disease. Ann Neurol 1996;40:678680.
16 Fallin D, Reading S, Schinka J, Hoyne J, Scibelli P, Gold M, Crawford F, Mullan M: No interaction between the APOE and the alpha1-antichymotrypsin genes on risk for Alzheimer's disease. Am J Med Genet 1997;74:192194.

17 Didierjean O, Martinez M, Campion D, Hannequin D, Dubois B, Martin C, Puel M, Thomas-Anterion $\mathrm{C}$, Pasquier $\mathrm{F}$, Moreau $\mathrm{O}$, Babron MC, Penrt C, Agid Y, Clerget-Darpoux F, Frebourg T, Brice A: No effect of the alpha-1antichymotrypsin A allele in Alzheimer's disease. J Neurol Neurosurg Psychiatry 1997;63: 103-105.

18 Helisalmi S, Mannermaa A, Lehtovirta M, Ryynanen M, Riekkinen P Sr, Soininen H: No association between alpha-1-antichymotrypsin polymorphism, apolipoprotein $\mathrm{E}$ and patients with late-onset Alzheimer's disease. Neurosci Lett 1997;231:56-58.

19 Yoshizawa T, Yamakawa-Kobayashi K, Hamaguchi H, Shoji S: Alpha-1-antichymotrypsin polymorphism in Japanese cases of Alzheimer's disease. J Neurol Sci 1997;152:136-139.
20 Murphy GM Jr, Sullivan EV, GallagherThompson D, Thompson LW, van Duijn CM, Forno LS, Ellis WG, Jagust WJ, Yesavage J, Tinklenberg JR: No association between the alpha-1-antichymotrypsin A allele and Alzheimer's disease. Neurology 1997;48:13131316.

21 Yamanaka H, Kamimura K, Tanahashi H, Takahashi K, Asada T, Tabira T: Genetic risk factors in Japanese Alzheimer's disease patients: Alpha-1-ACT, VLDLR, and ApoE. Neurobiol Aging 1998(suppl 1):S43-S46.

22 Bass MP, Yamaoka LH, Scott WK, Gaskell PC, Welsh-Bohmer KA, Roses AD, Saunders AM, Haines JL, Pericak-Vance MA: No association of alpha-1-antichymotrypsin flanking region polymorphism and Alzheimer disease risk in early- and late-onset Alzheimer disease patients. Neurosci Lett 1998;250:79-82.

23 Itabashi S, Arai H, Matsui T, Matsushita S, Muramatsu T, Higuchi S, Trojanowski JQ, Sasaki H: Absence of association of alpha-1-antichymotrypsin polymorphisms with Alzheimer's disease: A report on autopsy-confirmed cases. Exp Neurol 1998;151:237-240. 